\title{
O REI DA VELA, A NAVALHA NA CARNE E A EVOLUÇÃO DO PERSONAGEM HOMOSSEXUAL NO TEATRO BRASILEIRO
}

O REI DA VELA, A NAVALHA NA CARNE AND THE EVOLUTION OF THE HOMOSEXUAL CHARACTER IN BRAZILIAN THEATRE

O REI DA VELA, A NAVALHA NA CARNE Y LA EVOLUCIÓN DEL PERSONAJE HOMOSEXUAL EN EL TEATRO BRASILEÑO

Carolina de Melo Ferraresi

Carolina de Melo Ferraresi Mestranda no PPG em Artes Cênicas na Escola de Comunicações e Artes da Universidade de São Paulo. Atriz, produtora e arte-educadora. 


\section{Resumo}

Este artigo aborda dois personagens interpretados pelo ator Edgard Gurgel Aranha, falecido em 1990, em duas peças estreadas em 1967, O rei da vela e A navalha na carne. A partir de entrevistas com o próprio Edgard e com o ator Sérgio Mamberti, notícias de jornal e críticas da época, traça-se um panorama da evolução do personagem homossexual, refletindo o momento atual com base em obras tão emblemáticas e importantes para o teatro nacional.

Palavras-chave: Teatro Brasileiro, Homossexualidade, História do Teatro Brasileiro.

\section{Abstract}

This article approaches two characters interpreted by the actor Edgard Gurgel Aranha, who died in 1990, in two plays released in 1967, O rei da vela and $A$ navalha na carne. From interviews with Edgard himself and the actor Sérgio Mamberti, and from archives such as newspapers and reviews of that time, we draw a panorama of the evolution of the homosexual character and analyze the current moment, considering emblematic and important works for the national theater scenario.

Keywords: Brazilian Theater, Homosexuality, History of Brazilian Theater.

\section{Resumen}

Este artículo aborda dos personajes interpretados por el actor Edgard Gurgel Aranha, fallecido en 1990, en dos piezas estrenadas en 1967, El rey de la vela y Navaja en la carne. A partir de entrevistas con el propio Edgard y con el actor Sérgio Mamberti, con noticias de periódicos y críticas de la época, se traza un panorama de la evolución del personaje homosexual y refleje el momento actual, a partir de obras emblemáticas e importantes para el teatro nacional.

Palabras clave: Teatro Brasileño, Homosexualidad, Historia del Teatro Brasileño. 


\section{Teatro, viado e fita-crepe}

Citando Marcelo Drummond, do Teatro Oficina, com sua paródia sobre Cacilda Becker, em que dizia "não existe teatro sem viado e fita-crepe,"' Ferdinando Martins lembra a quase onipresença dos homossexuais no campo das artes cênicas. A aproximação desses sujeitos foi objeto de especulações, e segundo Laurence Senelick "o caráter confessional da experiência teatral seria uma chave de explicação para esse fenômeno" (apud MARTINS, 2011). Desse modo, pode-se aferir que, se para Cacilda Becker e outras atrizes de sua geração o palco funcionava como uma borracha capaz de apagar características físicas, sociais e de gênero (PONTES, 2010), para os homossexuais, por outro lado, o palco acolhia e abraçava aquilo que, fora dele, era preciso disfarçar, esconder, dissimular. Atualmente, pode-se ver quanto essas questões avançaram na dramaturgia nacional, refletindo a evolução social ocorrida não apenas no Brasil, mas no mundo todo, advinda a partir da teoria queer, por exemplo. Porém, em 1960, o movimento gay ainda engatinhava, e a homossexualidade era tratada como patologia pela psiquiatria. A retirada do termo "homossexualismo" (que passou a receber o sufixo "ade" e não "ismo", que indicava doença) aconteceu apenas em 1973 (MILHORANCE, 2012), e apenas em 2013 o Manual de diagnóstico e estatístico de transtornos mentais (APA, 2014) removeu de sua lista de transtornos e patologias a transexualidade.

Sem pretender reconstituir uma história da sexualidade no Brasil, cabe ressaltar que em nossa cultura a homossexualidade ultrapassa questões de gênero ao incutir misoginia em seus espaços de circulação, além dos preconceitos já vividos cotidianamente pelos homossexuais. Albuquerque (2004) classifica a homofobia como um medo baseado na diferença sexual, uma defesa contra a ideia de que um homossexual pode experimentar os prazeres sexuais de uma mulher, o que tenderia a abolir a diferença entre os sexos. Nada mais ameaçador, em uma sociedade patriarcal, do que perder os poderes e privilégios de dominação. Nada mais ameaçador, em uma sociedade patriarcal, do que ser comparado a uma mulher. Afinal, em uma sociedade

1. É de Cacilda Becker a autoria da frase, tão famosa no meio teatral, "Não existe teatro sem fita-crepe". 
heteronormativa e extremamente machista como a brasileira, em que a população LGBT e feminina são as que sofrem as maiores taxas de mortalidade, ${ }^{2}$ carregar trejeitos ou qualquer outro símbolo que remeta à feminilidade seria uma humilhação.

No teatro brasileiro, o homoerotismo esteve presente desde o final do século XVIII, época em que as mulheres foram proibidas de atuar, através de decreto de D. Maria I, em 1780. A intenção da rainha era proteger as mulheres diante dos cômicos e empresários do ramo, vistos como gente "ordinária". Dessa maneira, os homens (negros e mulatos, na condição de escravidão ou já libertos) assumiam todos os papéis, e o teatro ganhava, como aponta João Silvério Trevisan (2002), uma "cena travestida". Mesmo o decreto tendo sido revogado em 1800, algumas companhias introduziam clandestinamente mulheres no elenco. Enclausuradas nas tarefas domésticas, as mulheres que se aventurassem à profissão de atriz estariam condenadas a reprovação social. Com a vinda de D. João VI, companhias portuguesas se apresentavam frequentemente no Rio de Janeiro, e aos atores negros sobravam papéis de pouco destaque. Isso mudou apenas com a renúncia de D. Pedro I, em 1831, fato que provocou uma onda nacionalista e xenofóbica no Brasil, afetando também os palcos. Trevisan, ao se referir a esta cena travestida, ressalta:

O fenômeno do travestismo em teatro não ocorria apenas nos grandes centros urbanos. Em Porto Alegre, por volta de 1830, existiu uma certa Sociedade do Teatrinho que mantinha em seu elenco alguns rapazes especializados em papéis femininos. Na mesma cidade, ainda por essa época, os cronistas mencionaram um certo Pedro Nolasco Pereira da Cunha, que era "inexcedível nos papéis femininos". (TREVISAN, 2002, p. 143)

Para Trevisan, essa prática de travestismo teatralizado acabou resultando em outras duas práticas: a do carnaval e a do ator-transformista. Estes puderam encontrar espaço para atuar nas revistas musicais ou em teatro de revista, que surgira em meados do século XIX, trazido da França. Artur Azevedo, por exemplo, especializou-se no gênero, que de forma cômica e

2. Em 2016, a ONG Grupo Gay da Bahia registrou 343 assassinatos no país da população LGBTQ. É imperativo saber que essas mortes são subnotificadas, ou seja, nem todos os crimes são registrados (MADEIRO, 2017). 
abrasileirada repassava os acontecimentos daquele ano, resumidos em esquetes entrecortados por músicas e beldades.

Na década de 1950 o teatro de revista ainda resistia e faturava, e a Companhia Walter Pinto, do produtor e autor, trouxe para o Brasil um grupo de artistas para atuar no espetáculo É fogo na jaca!. No grupo estava o ator-transformista português Ivan Vitor Ulisses Damião, que apresentou neste e em outros espetáculos da companhia sua personagem Ivaná, nome com o qual viria a se identificar no feminino, anos depois. Nos espetáculos em que atuou, Ivaná era a vedete, e não o "fresco". Nos personagens do teatro de revista existiam alguns tipos que eram representados frequentemente: o compadre, o malandro, a mulata, o caipira, o português, a mulher fatal etc. O sexo era introduzido em piadas de duplo sentido (double sens, em francês), sem, no entanto, utilizar-se de palavrão. Porém, isso iria mudar até 1964, quando cada vez mais o nu feminino foi explorado através das vedetes (VENEZIANO, 2006). Foi na figura do "fresco", e posteriormente do "entendido", que a homossexualidade masculina começou a aparecer nos palcos, ainda muito timidamente.

Tratada como crime desde as épocas coloniais, a homossexualidade sempre foi vista como um ato de transgressão. No Brasil recebeu estudos de pesquisadores como Peter Fry, antropólogo nascido na Inglaterra que se mudou para o Brasil e lecionou na Universidade Estadual de Campinas (Unicamp), onde iniciou seus estudos sobre homossexualidade. É importante notar como a linguagem evolui de acordo com as próprias questões que se modificam no decorrer do tempo. Em Fry (1985) surgem termos que atualmente estão em desuso, como o prefixo "ismo", indicando patologia nos homossexuais, e o artigo masculino para referir-se à travesti Fedra de Córdoba. O autor também cita a importância do Grupo Gay da Bahia, que foi o responsável pela extinção do código INPS do item 302.0, que desclassificava a homossexualidade como desvio mental. De Caetano Veloso e sua "É proibido proibir", Fry caminha até os Dzi Croquettes, um grupo que conseguiu passar despercebido pela censura com um show que misturava música, dança e humor, mas que não revelava explicitamente toda sua crítica ao machismo e ao preconceito de então. Sutilmente, eles afirmavam "Nós não somos homens, nem somos mulheres. Nós somos gente, computada igual a vocês!". Em meio a números 
de canto e dança, os Dzi Croquettes exibiam os corpos: barba, pelos, batom e cílios harmonizavam-se em corpos extremamente masculinos e torneados, que se movimentavam com leveza e feminilidade no palco. Segundo o jornal O Diário de Bauru, o grupo foi definido como "homens-mulheres dançando ao fascínio-pânico do público paulistano” (apud LOBERT, 2010, p. 243).

A pesquisadora Rosemary Lobert, que conviveu por um período com os Dzi Croquettes, identifica uma das principais características do grupo, a "androginia", como uma classificação perigosa. A androginia, que seria a junção de características masculinas e femininas, passou a ser repercutida na imprensa e no público de forma a associá-la a homossexualidade, e de modo preconceituoso, como explica a autora: "Em suma, apesar da postura dos atores e da aceitação da peça pelo público em geral, a palavra e categoria 'indefinida' viu-se pouco a pouco ‘definida”' (LOBERT, 2010, p. 242). Contudo, o grupo tentava reforçar sua posição ao combater a visão de que eles representariam o "gay power", assumindo que "Ou a gente representa a todos ou então não representa nada". Sendo descomprometidos com qualquer uma das causas a que eram associados, os Dzi acabaram abrindo espaço para que outros grupos tomassem a dianteira da vanguarda teatral.

\section{A navalha na carne e Veludo}

Filho de Julieta e Oswaldo Gurgel Aranha, Edgard Gurgel Aranha cresceu na cidade de São Paulo em um ambiente relativamente privilegiado, começando a estudar interpretação na Academia de Rádio e Televisão em São Paulo. ${ }^{3}$ Seu pai Oswaldo foi jornalista e diretor do Diário de São Paulo, e também do Diário da Noite, que tinha circulação pelo interior paulista. Edgard foi presença constante nos jornais, a partir de 1959 até a data de sua morte, já que fatos de sua vida eram noticiados, desde peças que estavam em cartaz, sua prisão em 1971, ${ }^{4}$ e eventos cotidianos e corriqueiros, como a viagem que realizou aos Estados Unidos. ${ }^{5}$ Edgard ingressou na Escola de Arte Dramática (EAD) em 1959, e formou-se em 1962. Em sua turma também estavam Juca de

3. Para saber mais, ver https://bit.ly/2MI3VOU.

4. Jornal do Brasil, 1 set. 1971.

5. Fonte: https://bit.ly/2NT9hec. 
Oliveira (que não concluiu o curso), Aracy Balabanian, Ademir Rocha, Carlos Eugênio M. Moura, Gilberto de Nichile, Luiz Nagib Amary, Nilson Demange e Ricardo de Lucca. Edgard ainda trabalharia com Aracy em Hair, anos depois. A atriz, na ocasião em que esteve preso em Belo Horizonte, devido a flagrante delito por posse de maconha e outras substâncias, prestou depoimento em seu favor na delegacia.

Anos depois, após ter passado pelo Grupo Decisão (que tinha Antônio Abujamra como diretor principal), Edgard começou uma série de leituras do mais recente texto de Plínio Marcos, A navalha na carne. Dos ensaios à estreia, a montagem resumiu-se a uma verdadeira odisseia. O ano era 1967, o regime ditatorial completava três anos, desde o golpe militar que depôs o presidente João Goulart. A censura (que sempre esteve presente na imprensa e no teatro, desde as mais remotas épocas coloniais) começou a ficar cada vez mais rigorosa. Os grupos de teatro, antes de estrear, eram obrigados a agendar um ensaio exclusivo para os censores, que assistiam a tudo e, ao final, faziam perguntas e sugeriam mudanças. Como conta José Carlos dos Santos Andrade (2013, p. 65-88):

De forma geral, os olhares dos censores estavam sempre voltados para os chamados "palavrões", ou termos de baixo calão, considerados inadequados para os ouvidos do público espectador. Mesmo quando o contexto da peça envolvesse personagens que faziam uso desse linguajar naturalmente em seu cotidiano, como é o caso das peças de Plínio Marcos, esses "palavrões" deveriam ser suprimidos, ou no mínimo substituídos por outras palavras que não causassem o mesmo impacto.

Com $A$ navalha na carne o processo não foi diferente. Sábato Magaldi e Maria Thereza Vargas (2001, p. 44) descrevem a mobilização da classe teatral pela liberação do texto, censurado em grande parte. Após as leituras realizadas no Teatro de Arena, posteriormente na casa de Cacilda Becker e Walmor Chagas, por Tônia Carrero, e, finalmente, após o lançamento de um ensaio fotografado, o elenco conseguiu a liberação da peça para maiores de 21 anos, que estreou em 12 de setembro de 1967 no Teatro Maria Della Costa, em São Paulo.

Já $O$ rei da vela estreou em 3 de outubro daquele mesmo ano, data de reabertura da sede do Teatro Oficina, que havia acabado de passar por uma reforma logo após um incêndio (que muitos, incluindo José Celso Martinez 
Corrêa, consideram criminoso). O texto de Oswald de Andrade é de 1933, e foi escolhido pelo diretor Zé Celso para simbolizar a volta do grupo. A opção por um texto nacional indicava a mudança estética do grupo, que até então havia feito sucesso com autores estrangeiros. Segundo Sábato Magaldi, a peça revelava a "chacriníssima imagem do país" (MAGALDI; VARGAS, 2011, p. 46). Edgard interpretava o personagem Totó Fruta-do-Conde, e o elenco contava ainda com Renato Borghi, Etty Fraser, Liana Duval e Dirce Migliaccio, entre outros.

A homossexualidade como tema no teatro teve uma explosão recente, mas começou a aparecer justamente nos anos 1960, a partir de autores como José Vicente e Antônio Bivar. Data de 1967 o primeiro texto de José Vicente, Santidade, que conta a história de um ex-seminarista que recebe a visita do irmão, prestes a se ordenar como padre. O diferencial está justamente no fato de que o personagem principal vive auxiliado financeiramente por seu amante. O espetáculo foi censurado diretamente pelo então presidente Costa e Silva, que fez uma aparição na televisão e chegou a advertir que aquele era o tipo de espetáculo que jamais seria encenado no país (MORAIS, 2010). O texto permaneceu engavetado por trinta anos. Também é de 1967 Cordélia Brasil, texto de Antônio Bivar, que conta a história de uma mulher que se sacrifica pelo homem amado, trabalhando e se prostituindo para sustentá-lo. Quando ela leva para casa um jovem de 16 anos, o texto sugere uma tensão sexual entre seu companheiro e o adolescente.

Foi com Plínio Marcos que, definitivamente, o público viu nos palcos uma revolução em torno de personagens marginalizados. Sérgio Mamberti, ator, diretor e amigo de Edgard Gurgel Aranha, destaca o modo como os homossexuais eram representados no teatro, em entrevista concedida ao programa Persona em Foco da TV Cultura, de 15 de setembro de 2015:

E como era a primeira vez que um personagem homossexual era feito de verdade, não como uma caricatura, e a peça tinha essa aura toda, todo mundo se pegou na liberação, a Cacilda Becker se apaixonou pela peça, e colocou o Plínio num patamar que nunca tinha tido antes, ele já tinha outras obras, mas a Navalha deu essa projeção nacional. 
Jairo Arco e Flexa, diretor de Navalha, na mesma entrevista, pede a Sérgio Mamberti que conte ao público como foi interpretar o personagem Veludo. Sérgio diz que a escolha recebeu inúmeras críticas, uma vez que interpretar um personagem homossexual poderia estigmatizar $\mathrm{o}$ ator para o resto de sua carreira.

A peça do Plínio surgiu como uma revelação e desvendando um universo muito cruel, o universo dos marginalizados da sociedade. A peça foi um sucesso extraordinário, e todo mundo falava, "Você acabou de ganhar o prêmio Saci, você vai fazer um 'viado'? Isso vai acabar com a tua carreira, nunca mais vão te dar nenhum papel!" Eu falei: "Eu não vou fazer só um viado. Eu vou fazer um homossexual pela primeira vez, respeitado nas suas características de cidadão". Porque o Plínio tinha um respeito profundo, ele tirou esse aspecto da caricatura do homossexual, e criou um personagem que ficava quinze minutos em cena, mas eu entrava e era aplaudido, e saía de cena aplaudido. Foi um dos trabalhos inesquecíveis da minha vida, e o Jairo fez um trabalho brilhante de direção, que tinha além de mim, o Paulo Villaça e Ruthinéia de Moraes em criações inesquecíveis. $E$ foi realmente, eu considero um dos trabalhos mais importantes destes sessenta anos de carreira.

Porém, para Sérgio, o estigma não permaneceu durante sua carreira de ator, ao contrário de Edgard, que trabalhou majoritariamente com personagens homossexuais, tanto no teatro quanto no cinema. Infelizmente, não é possível concluirmos se essa questão chegou ou não a ser um ponto de inflexão em sua carreira, pois esta é uma pesquisa póstuma. Seria leviano chegar a qualquer conclusão a respeito do tema e se ele estaria relacionado a suas escolhas profissionais. Erving Goffman (2017, p. 7) descreve o termo como "a situação do indivíduo que está inabilitado para a aceitação social plena". Assim, as relações sociais estariam divididas entre pessoas "normais", como chama o autor àqueles que não possuem estigmas, e os "diferenciados", que carregam por toda a vida ou a partir de algum momento marcante sinais que o identificam e o marginalizam dentro de suas próprias relações. Dessa maneira, estariam nessa categoria de diferenciados: prostitutas, homossexuais, mendigos, viciados em drogas, deficientes físicos, mentais, desempregados etc. Sabemos que, se atualmente é raro que um ator venha a público manifestar sua orientação sexual, nos idos dos anos 1960 e 1970 era quase uma 
regra que isso fosse mantido apenas no âmbito privado, pois tal informação seria capaz de destruir a carreira de um ator ou atriz. Apesar de toda a liberação sexual ocorrida a partir dos anos 1960 no mundo inteiro, influenciada pelos movimentos hippie e feminista, o conservadorismo ainda reinava na maior parte das relações sociais e profissionais.

Em uma das raras entrevistas encontradas, de 1972, Edgard conta que, para ele, o importante no teatro era o que se relacionava com sua vida. Ele considerou $A$ navalha um de seus trabalhos mais importantes, pelo qual era visto como um dos melhores atores do Brasil na época; mas ressalta que a peça era fácil de fazer, com três personagens estereotipados. Achava, inclusive, que Sérgio havia atuado melhor do que ele, pois Edgard o fazia de forma mais "trágica e patética" (PERFIL, 1972). É curiosa a crítica de Sábato Magaldi a Edgard, na peça Hair, que este estrelou em 1971: "E Edgar, que vem se especializando em certo tipo de papéis, não tem dificuldade em fazer, com graça, a senhora que vai dialogar com os hippies" (MAGALDI; VARGAS, 2011, p. 172).

Fica evidente que Sábato referiu-se ao fato de que Edgard estava interpretando, em sua maioria, personagens homossexuais e que tinha ficado estigmatizado por isso, algo comum ainda hoje na televisão, por exemplo, em que atores e atrizes quase sempre repetem os papéis de vilão e mocinho nas novelas.

São várias as críticas encontradas nos jornais sobre a peça, que vão de Yan Michalski (1932-1990), Anatol Rosenfeld (1912-1973), Sábato Magaldi (1927-2016), a Décio de Almeida Prado (1917-2000), entre outros. Magaldi assim resume a obra:

Neusa Suely, voltando ao quarto, encontra Vado na cama, a ler uma revista em quadrinhos. Ele nem havia saído: sem dinheiro, que fazer lá fora? Antes de revelar a Suely o motivo do mau humor, Vado exercita o seu sadismo, ela acredita numa intriga da vadia do 102. Garantindo Suely que deixou no criado-mudo o dinheiro, ocorre a suspeita de furto, e se Veludo seria responsável por ele. (MAGALDI; VARGAS, 2011, p. 172)

Assim começa o embate travado entre os personagens, que se revela uma luta de poder. Nas palavras de Anatol Rosenfeld (1993): 
O dinheiro ganho pela prostituta daqueles que a compram e que serve para comprar o rufião é roubado pelo homossexual para que possa comprar, por sua vez, um pouco de afeto. [...] "Será que somos gente?", pergunta a prostituta. Através da simplicidade desta pergunta transparece a gravidade e o pathos moral das indagações mais profundas da filosofia. Umas das fórmulas do imperativo categórico, na filosofia moral de Kant, estabelece que a dignidade da pessoa humana é ferida por quem a usa apenas como meio e não a trata, também, como fim em si mesmo, isto é, por quem transforma a pessoa em simples coisa e objeto, sem respeitar a sua condição humana de sujeito livre. E é exatamente neste ponto que a peça nos atinge a todos e reflete, ao desnudar os mecanismos elementares do submundo, problemas morais e sociais muito mais amplos.

Alberto D'Aversa, que foi professor de Edgard na EAD, dirige-se a Veludo em sua crítica (1967) como "pederasta", que àquela época era termo bastante utilizado para indicar uma perversão sexual, ou seja, a inclinação de um homem a fazer sexo com meninos ou adolescentes. Na verdade, era uma maneira pejorativa de se referir a homossexuais. Outros autores aludem a Veludo da mesma maneira, como Delmiro Gonçalves (1967), na crítica para o jornal O Estado de São Paulo naquele mesmo ano.

Sábato Magaldi considera que as personagens eram "talhadas com espírito de síntese", e "rastejam os seus sentimentos", pois, simbólica e literalmente, estão muitas vezes jogadas no chão. Da mesma maneira que Rosenfeld, Magaldi também se refere à frase da personagem Neusa Sueli: "Às vezes chego a pensar: porra, será que eu sou gente? Será que eu, você, o Veludo somos gente? Duvido que gente de verdade viva assim, aporrinhando o outro, um se servindo do outro". Pensando na sua própria humanidade, os personagens, que poderiam fazer parte do elenco daqueles diferenciados de que trata Erving Goffman ao falar do "estigma”, os marginalizados na peça, nos fazem refletir até hoje sobre a nossa própria condição.

\section{O Rei da Vela e Totó Fruta-do-Conde}

José Celso Martinez Corrêa fundou o Teatro Oficina em 1958, enquanto ainda estudava na Faculdade de Direito do Largo São Francisco, com seus colegas Amir Haddad e Carlos Queiroz Telles. A primeira montagem do grupo 
foi de autoria de Zé Celso, Vento forte pra papagaio subir, e, em seguida, $A$ ponte, de Carlos Queiroz Telles. Começando com textos quase autobiográficos e muito particulares, foi o Teatro de Arena (por meio de Augusto Boal, que deu os primeiros cursos de interpretação para o grupo) que inspirou seus integrantes a mudarem sua imagem para um teatro mais preocupado socialmente. Partindo para a profissionalização, encabeçaram sucessos de público com as montagens de autores estrangeiros até 1967, e com O rei da vela puderam retomar a ideia de uma interpretação totalmente brasileira ${ }^{6}$.

Van Jafa (1967) lembra-nos que na década de 1930 Bertolt Brecht já despontava na Alemanha com seu teatro épico, mas Oswald de Andrade, aqui no Brasil, estava longe de ser influenciado por ele. Porém a escolha de $O$ rei da vela pelo Teatro Oficina não foi aleatória: "Era preciso então reinventar o teatro" (MARTINEZ, 1998), como disse Zé Celso, ainda que fosse a partir de um texto de 34 anos antes. Oswald, um dos organizadores da Semana de Arte Moderna de 1922 (que, por sinal, considerou literatura e artes visuais, porém ignorou o teatro), começou a escrever peças depois de sua filiação ao Partido Comunista Brasileiro (PCB). Escreveu A morta em 1937 e O homem e o cavalo em 1934. Após tentativas de montar $O$ rei da vela, inclusive com o ator Procópio Ferreira em 1933, que declinou do convite por medo da censura, o texto foi publicado somente em 1937 e permaneceu engavetado por trinta anos.

Luiza Barreto Leite (1968) comenta este momento vivido pelo Teatro Oficina:

Até 1964 o Oficina procurava, na realidade internacional, o reflexo de nossos problemas. Seu ponto forte foi Máximo Gorki, que proclamou à gente de seu tempo verdades ainda desconhecidas no Brasil de hoje. E Os pequenos burgueses feriu fundo, mas emocionalmente, por isto não ofendeu. Sucesso absoluto. Depois foram necessárias as remontagens, pois, entre outros desastres, o incêndio do próprio teatro exigia sacrifícios econômicos. Os inimigos e Andorra diziam muito, mas não tudo, ou pelo menos não à nossa moda, do nosso jeito, para a nossa gente. Já estavam parecendo experiências estéticas de fuga pela tangente social. Era preciso pensar. Quatro num quarto serviu de pausa para meditação e Oswald de Andrade, "o maldito" da geração 22 foi redescoberto.

6. Para saber mais sobre as origens do Teatro Oficina, ler SILVA (2008). 
Presença eterna do poeta antropófago? Necessidade de novo surto de protesto destrutivo?

O diretor José Celso fez do espetáculo um manifesto, que serviu para denunciar a "permanência da velhice dos mesmos e eternos personagens" (MARTINEZ, 1998). Oswald de Andrade utilizou-se da história de um casal medieval, Heloísa e Abelardo, que trocaram cartas contando seu amor proibido (Abelardo era um padre), para criar o texto que se propunha a criticar o "velho teatro" de sua época. Sua estrutura dramatúrgica era composta por atos que se dividiam em circo, teatro de revista e opereta, e conta a história de Abelardo I, dono de uma firma de agiotagem, que pretende se casar com Heloisa, filha de um barão de café, utilizada como moeda de troca pela família. Depois de ir à falência e cometer suicídio, é substituído por Abelardo II, que por meio de um golpe que causou a ruína do primeiro, herda os negócios e a noiva.

Ao estrear, o Teatro Oficina publicou seu manifesto a respeito da peça:

O Oficina procurava um texto para a inauguração de sua nova casa de espetáculos que ao mesmo tempo inaugurasse a comunicação ao público de toda uma nova visão do teatro e da realidade brasileira. As remontagens que o Oficina foi obrigado a realizar por causa do incêndio estavam defasadas em relação a sua visão do Brasil desde anos, depois de abril de 1964. O problema era o do aqui-agora. E o aqui-agora foi encontrado em 1933 em O Rei da Vela de Oswald de Andrade. (MARTINEZ, 1998)

Na crítica de Yan Michalski (1968), cenário e figurinos (ambos de Hélio Eichbauer) contribuem para essa visão barroca, grotesca e exagerada pretendidas pelo grupo.

Pela primeira vez, vislumbro aqui o esboço de uma coisa que poderia, com algum otimismo, ser definida como um moderno estilo brasileiro de interpretação: uma fusão das técnicas modernas de anti-ilusionismo com nossas características nacionais de malícia grossa e avacalhada, fusão esta conseguida com a ajuda de amplo aproveitamento - naturalmente devidamente estilizado e criticado - dessa nossa grande tradição cultural, a chanchada. 
Sobre a construção da linguagem corporal dos personagens, Décio de Almeida Prado (1967) aponta para a carga sexual da peça: "O sexo é usado mais do ponto de vista do símbolo fálico masculino, que acompanha o homem brasileiro desde o ginásio até a senilidade, nunca figurando, entretanto, no seu mundo oficial".

Armando Sérgio da Silva (2008) indica que a linguagem sexual faz jus ao discurso de poder proferido pelos personagens, misturado com "uma forte dose de machismo bem brasileiro". O autor descreve a postura de Abelardo I durante o primeiro ato, como ereta, enquanto nos outros personagens a postura era quase horizontal. Era clara a alusão à penetração sexual quando Abelardo I movia a pélvis de um jeito malandro, quando parecia coçar seu órgão sexual. Não podemos nos esquecer da vela, usada como símbolo fálico por Abelardo II, que penetraria então o I, sucedendo ao poder. Sobre a composição dos personagens, cada ator inspirou-se em personalidades da época para representar seus lugares na sociedade retratada: a esposa de um político por Etty Fraser, Getúlio Vargas e João Goulart por Fernando Peixoto, Ademar de Barros e Chacrinha por Renato Borghi etc.

Sobre Edgard, Luiza Barreto Leite (1968) escreve:

Totó Fruta-do-Conde é trazido por Edgard Gurgel Aranha, ao nosso baile no Municipal, com vastas possibilidades de ser incluído no próximo desfile das escolas de samba. Perfeito. Quantos espectadores se identificaram? E quantos com o intelectual Pinote? Parabéns Edgard.

Anatol Rosenfeld (1993), sobre o teatro agressivo feito pelo Teatro Oficina, escreveu: "O espetáculo agride intelectualmente, formalmente, sexualmente o espectador, isto é, chama às vezes o espectador de burro, recalcado, reacionário. José Celso pretende esbofetear o público, fazê-lo engolir sapos e até jiboias". Parece que o mesmo esquema de segurança relembrado por Sérgio Mamberti em A navalha na carne, que estreou no mesmo ano de $O$ rei da vela, foi adotado pelo Teatro Oficina. Algumas pessoas da plateia sentiam-se ofendidas pelos discursos durante a peça, e o grupo sofreu ameaças, passando então a contar com dois homens na coxia, que observavam a reação do público e estavam a postos para qualquer ameaça à segurança dos atores. Posteriormente, com a estreia do texto de Chico Buarque, Roda-Viva, em 18 de julho de 1968, 
José Celso experimentou na pele os tempos de ódio da Ditadura, quando uma das sessões do espetáculo foi invadida pelo CCC (Comando de Caça aos Comunistas), que interrompeu a peça e agrediu fisicamente os atores.

Iná Camargo, utilizando-se da crítica de Alberto D’Aversa ao espetáculo, indica os preconceitos do dramaturgo que foram exacerbados por José Celso, ao utilizar-se da sátira nos moldes do então "velho teatro de revista" ao pederasta, à lésbica, ao coronel ou à velha tia. Para a autora, o grupo, que mesmo com o Al-5 conseguiu a liberação da peça, não era de maneira nenhuma "marginal" como acreditava ser, e levava os créditos daqueles que criticavam: "Para estes, revigorava-se a tese [...] de que o contrário do burguês não é o proletário, mas o boêmio" (COSTA, 1996, p. 174). Mesmo em Roda-Viva a autora indica que na direção de José Celso há uma combinação estranha de moralismo e agressão. Ela relembra Antonin Artaud, poeta, ator, diretor e escritor francês que, em vez da agressão, propunha a comunhão com a plateia. Coisa que o diretor, segundo ela, não conseguiu, subvertendo a ideia do teatro da crueldade de Artaud.

Se poucos foram os críticos que encontraram defeitos na peça, como Décio de Almeida Prado e Iná Camargo, muitos teceram elogios ao trabaIho de interpretação dos atores. O próprio Décio considera que a peça foi o apogeu do Oficina. Sábato Magaldi destaca a unicidade factual do elenco. Yan Michalski considera que alguns atores não obtiveram o mesmo brilho de Renato Borghi, como Edgard, que poderia ter algumas cenas cortadas no segundo ato.

Críticas à parte, é incontestável o impacto causado por O rei da vela do Teatro Oficina. Para Ferdinando Martins (2010), Zé Celso “antecipa a estética queer e subverte o preconceito". Entre percepções tão díspares a respeito de obra tão controversa, não podemos negar que o espetáculo é considerado um marco na história do teatro brasileiro. Como pensavam os críticos da época, já era tempo de o teatro ser um ato revolucionário por si só.

\section{Conclusão}

De Ivaná do teatro de revista aos Dzi Croquettes, de Totó Fruta-doConde a Veludo, até caminhar lentamente para o que hoje entendemos como 
um teatro e performance queer, ${ }^{7}$ o teatro brasileiro refletiu e fez refletir as questões de gênero e sexualidade das realidades que o cercam. Seria objeto de outro artigo elencar as encenações atuais que abordam temas como homossexualidade, transexualidade, aids e tudo que faz parte dessa "caixa" que quer ser rompida, a denominada cultura queer. Se no teatro do passado a homossexualidade era tratada ainda com resquícios dos estereótipos trazidos do teatro de revista (que deixou sua herança não apenas no teatro, mas até nas novelas), se era vista como perversão ao ser tratada como pederastia, se foi retirada do rol de doenças comportamentais apenas em 1973, tais fatos foram somente reflexo de tempos não tão distantes.

Por outro lado, atualmente a questão homossexual ultrapassou os limites físicos das paredes dos teatros e ganhou as ruas. Podemos ver, por exemplo, o Coletive Friccional, com sua performance Contar os corpos e sorrir?, que trouxe para o meio da Avenida Paulista dezenas de corpos embalados em sacos plásticos, referenciando os assassinatos da população LGBTQ. Se em décadas anteriores os atores eram ameaçados dentro dos teatros e precisavam contar com uma escolta para segurança, levar a performance para o espaço público escancarou os preconceitos e violência que essa população sofre em qualquer lugar: dentro de casa, às vezes da própria família, e fora dela.

Dos anos 1960 em diante, a história do teatro brasileiro passou por inúmeras pequenas revoluções. Algumas peças trouxeram personagens ou debates sobre a homossexualidade desde então: Agreste e A cicatriz é a flor, de Newton Moreno; Anatomia do Fauno, dirigida por Marcelo Denny e Marcelo D’Avilla; Maria que virou Jonas, da Cia. Livre; O evangeIho segundo Jesus, Rainha do céu (que inicialmente sofreu censura e foi proibida de apresentar na cidade de Jundiaí (O GLOBO, 2017)), de Natalia Mallo, entre outras.

A professora, escritora e pesquisadora Dodi Leal, ativista e militante LGBTQ, afirmou, no Congresso Anual da International Federation for Theatre Research (IFTR) de 2017, que "ser famoso protege a vida das pessoas

7. No correspondente português "excêntrico", queer é termo que começou a ser mais utilizado em meados dos anos 1990, graças à obra Problemas de gênero, da filósofa Judith Butler. Tudo aquilo considerado fora da norma heterossexual ou que segue um padrão binário em relação a orientação sexual ou identidade de gênero seria considerado queer. 
transexuais". Através do teatro, do cinema, da televisão ou da música, a arte não apenas tem o poder de proteger essas pessoas, sejam elas "famosas" ou não, mas também é capaz de despir preconceitos e levar novos pensamentos a várias camadas da sociedade, para que no futuro não seja mais preciso contar corpos, e sim deixá-los viver.

\section{Referências bibliográficas}

ALBUQUERQUE, Severino J. Tentative transgressions: homossexuality, aids and the theater in Brazil. Madison: The University of Wisconsin Press, 2004.

ALMEIDA PRADO, Décio de. A encenação de "O rei da vela". O Estado de São Paulo, São Paulo, 20 out. 1967.

AMERICAN PSYCHIATRIC ASSOCIATION - APA. Manual diagnóstico e estatístico de transtorno mentais. Porto Alegre: Artmed, 2014.

ANDRADE, José Carlos dos Santos. Teatro e censura: plateia vazia e atores calados. Arterevista, v. 1, n. 1, p. 65-88, jan./jun. 2013.

BUTLER, Judith. Problemas de gênero: feminismo e subversão da identidade. 8. ed. Rio de Janeiro: Civilização Brasileira, 2015. (Coleção Sujeito \& História).

COSTA, Iná Camargo. A hora do teatro épico no Brasil. Rio de Janeiro: Paz e Terra, 1996.

D’AVERSA, Alberto. 16/09/1967. Uma velha navalha em mãos novas. 16 set. 1967. Disponível em: <https://goo.gl/ttXDXS>. Acesso em: 31 mar. 2018.

FRY, Peter; MACRAE, Edward. O que é homossexualidade. São Paulo: Brasiliense, 1985.

GOFFMAN, Erving. Estigma: notas sobre a manipulação da identidade deteriorada. Rio de Janeiro: LTC, 2017.

GONÇALVES, Delmiro. Quando a navalha é afiada. O Estado de São Paulo, 12 set. 1967. Disponível em: <https://goo.gl/ShUD3B>. Acesso em: 31 mar. 2018.

LEITE, Luiza Barreto. O rei da vela. Jornal do Commercio, 14 jan. 1968.

LOBERT, Rosemary. A palavra mágica: a vida cotidiana dos Dzi Croquettes. São Paulo: Editora da Unicamp, 2010.

MADEIRO, Carlos. ONG aponta recorde de LGBTs mortos no Brasil em 2017: "Dói só de lembrar", diz parente. UOL Notícias, 25 set. 2017. Disponível em: <https://bit. ly/2wSxAwb>. Acesso em: 15 mar. 2018.

MAGALDI, Sábato; VARGAS, Maria Thereza. Cem anos de teatro em São Paulo (1875- 1974). 2. ed. São Paulo: Editora Senac São Paulo, 2001.

MARTINEZ, José Celso. Primeiro ato: cadernos, depoimentos, entrevistas (19581974). São Paulo: Editora 34, 1998. 
MARTINS, Ferdinando. Cenas paralelas: do arcaico ao pós-moderno nas representações do gay no teatro brasileiro contemporâneo. In: COSTA, Horácio et al. (Org.). Retratos do Brasil homossexual: fronteiras, subjetividades e desejos. São Paulo: Edusp; Imprensa Oficial, 2010.

Gênero e interdição: as mulheres no teatro brasileiro sob a ótica da censura. São Paulo: Edusp, 2011.

MICHALSKI, Yan. O rei da vela. Jornal do Brasil, Rio de Janeiro, 17 jan. 1968.

MILHORANCE, Flávia. Mais um ponto final na luta dos homossexuais. O Globo, 15 dez. 2012. Disponível em: <https://glo.bo/2OzOysT>. Acesso em: 17 jul. 2017.

MORAIS, Cida. $O$ teatro de José Vicente: primeiras obras. São Paulo: Imprensa Oficial, 2010. (Coleção Aplauso).

O GLOBO. Censurada em Jundiaí peça com atriz transexual interpretando Jesus é liberada em Porto Alegre. O Globo, Rio de Janeiro, 20 set. 2017. Disponível em: $<$ https://goo.gl/sFdsdi>. Acesso em: 15 mar. 2018.

PERFIL. Edgar Gurgel Aranha. Palco + Plateia, São Paulo, ano III, p. 27, mar. 1972. PONTES, Heloísa. Intérpretes da metrópole. São Paulo: Edusp, 2010.

ROSENFELD, Anatol. Prismas do teatro. São Paulo: Perspectiva, Edusp; Campinas: Editora da Unicamp, 1993.

SILVA, Armando Sérgio da. Oficina: do teatro ao te-ato. 2. ed. São Paulo: Perspectiva, 2008.

TREVISAN, João Silvério. Devassos no paraíso: a homossexualidade no Brasil, da colônia à atualidade. 5. ed. Rio de Janeiro: Record, 2002.

VAN JAFA. O rei da vela. Correio da Manhã, Rio de Janeiro, 26 nov. 1967, p. 2. Disponível em: < https://goo.gl/eiBuCu>. Acesso em: 18 set. 2018.

VENEZIANO, Neyde. De pernas para o ar: teatro de revista em São Paulo. São Paulo: Imprensa Oficial, 2006. (Coleção Aplauso).

Recebido em 14/03/2018

Aprovado em 16/08/2018

Publicado em 25/10/2018 